of colouring into as small a space as possible, and afterwards elaborating the more interesting details of habits and distribution. As in all Mr. Kearton's books, the great attraction is, however, the illustrations, which are from photographs by himself and his brother; and in this volume, were we not afraid of libelling their earlier efforts, we should be tempted to say that the artists have surpassed themselves. Be this as it may, the charming illustrations in this volume would be hard to beat, as our readers may judge for themselves from the sample here reproduced (Fig. 1), which was selected almost at random, as where all are excellent it is difficult to make a choice. A more attractive gift-book for young people fond of birds-as all of them should be, and probably are, when they have the proper opportunities--would be difficult to find.

The third volume in the list is, as implied by its title, less of a purely natural history than either of

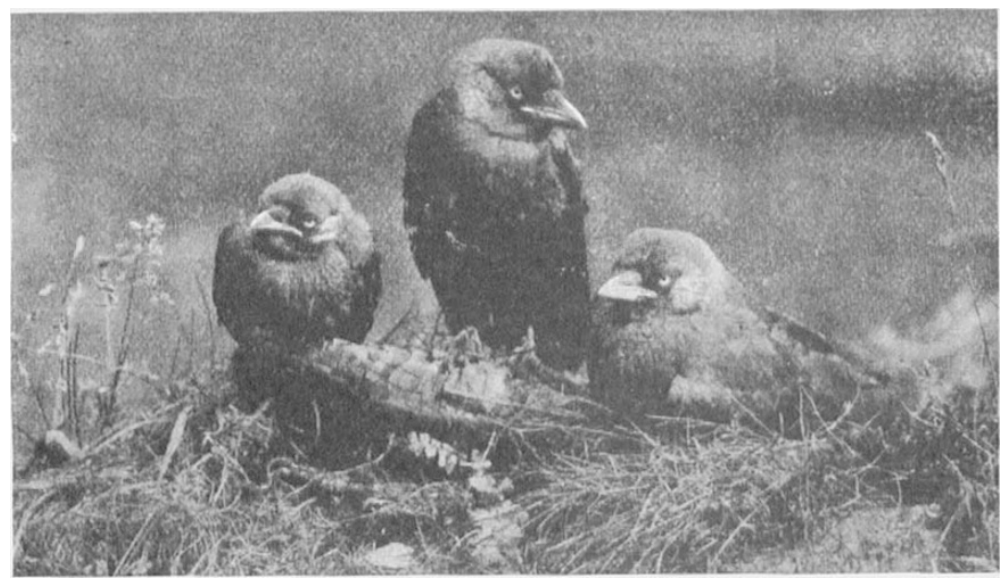

Fig. 2.-Young Rooks. From "I Go A-Walking."

the two preceding ones, dealing largely with country scenery and country life; the frontispiece depicts a beautiful scene from an old-fashioned English hamlet with thatched cottages, while other illustrations show no less exquisite glimpses of shore and river landscape. Certain chapters, such as the one on the flight of the swift and another on the song of the skylark, are, however, vivid sketches of phases in the habits and life-history of birds possessing a peculiar interest and charm of their own; and it is only lack of space that prevents our dwelling on these at some length. Both those mentioned are jllustrated with photographs of the species to which they are respectively devoted, and many readers will be specially interested in the author's observations with regard to the nocturnal flight of the swift. In saying that $\mathrm{Mr}$. Tickner Edwardes's little volume, although written on different lines, vies in interest with Sir Herbert Maxwell's "Memories of the Months "we are bestowing a very high meed of praise.

"I Go A-Walking," which is dated 1907, although it was previously issued in parts, and the first of these noted in our columns on its first appearance, is a series of brief illustrated biographies of certain selected birds and animals. 'These are, no doubt, excellent in their way, but the charm of the book lies in the illustrations; and since these are reproductions from photographs by Mr. C. Reid, of Wishaw, it would be waste of words to add anything in the way of commendation. A special feature of the work is NO. I9.38, vOL. 75$]$ the number of illustrations of groups of young birds, and that our readers may judge for themselves as to the excellence of these (and the illustrations generally) we reproduce, by the courtesy of the publisher, one showing a trio of young rooks.

The fifth book on our list is on a higher plane and of a type totally different from any of the others, dealing mainly with animal psychology, and revealing the thoughtful and speculative mind of the talented author. To do justice to Mr. Long's ideas and theories in the space of a few lines is a manifest impossibility, and we must be content to refer to his belief that the lower animals "possess a rudimentary mind," and may therefore be accorded "some small chance for immortality." With these sentiments we have no cavil, but when we read the statement that "death to the animal is but a sleep, and the only thought in his head when he lies down for the last time is nature's whisper that he will waken as usual when the right time comes," we would ask the author how many wild animals die, so to speak, in their beds? With this brief notice we must leave (and commend) a thoughtful work to the best attention of earnest and thoughtful readers.

Last, and likewise least, is the little volume on birds in Miss Chisholm's "Shown to the Children" series. In works of this nature the necessity for abundant illustration over-rides all other considerations, and if in this instance quantity somewhat exceeds quality, it must be borne in mind that forty-eight full-page coloured plates form a very liberal allowance in a halfcrown book, and that the style of execution will probably pass muster among the readers of the book. If we except a few sentences, such as the statement that blackbirds eat snails, the letterpress appears in the main to be just what should be provided for very juvenile readers.

R. L.

\section{THE TREATMENT OF CANCER.}

$\mathrm{T}$ is an appropriate coincidence that the sensational statements made in the daily Press last week respecting the cure of cancer should have as their antidote the scientific discourse "On the Treatment of Cancer by Modern Methods," which was delivered" at the Royal College of Surgeons, as the Bradshaw lecture, by Mr. Edmund Owen on December 12. In an article in the Pall Mall Gazette Dr. Saleeby went so far as to assert that the conquest of cancer is within measurable distance, the means of cure being trypsin, a digestive ferment formed by the pancreas and passed in its secretion into the duodenum-the upper part of the small intestine.

The use of trypsin as a cure for cancer seems to have suggested itself independently to two observers, Mr. J. Beard and Dr. Shaw-Mackenzie, the former apparently on embryological grounds, and the latter because of the comparative immunity of the small intestine from cancer. 'Thus, in 105,374 cases of cancer of the digestive tract, the small intestine was affected in only twenty. ${ }^{3}$ Beard found that in mice, the subjects of experimental cancer (the Jensen

Shaw-Mackenzie, Brit. Mer. Tourn., 19c6, i., p. 715. 
tumour), injections of trypsin caused shrinkage and degeneration of the tumours, ${ }^{1}$ a not unlikely event considering the active digestive properties of trypsin, and his method is stated to have been carried out with success in the human subject by Prof. Morton in America.

The full report of the work of Prof. Morton will be awaited with interest; but, in the meantime, the premature publication of details cannot be too strongly condemned. It is well known that trypsin has been tried in this country by many without any startling success; it is possible that it may be valuable in certain localised growths, just as radium and the $\mathrm{X}$-rays are in selected cases, but, on the data available, to assert that the conquest of cancer is near at hand is unreasonable, and does infinite mischief to science as well as increasing the suffering of the unfortunate victims of this dire malady by hopes that are destined not to be realised.

With reference to Mr. Beard's experiments on mouse cancer, it is to be noted that this so-called experimental cancer is an implantation of the disease into an animal, and not a cancerous metamorphosis of the animal's own tissues, a thing very different from spontaneous cancer. Chian turpentine, violet leaves, Doyen's serum, and a host of other remedies have all at some time or other been vaunted as specifics for cancer, but none has stood the test of rigorous trial.

In conclusion, an extract from the Bradshaw lecture may be quoted :-

"Surgery must not go in advance of facts, or she will assuredly be overtaken and tripped up, as she has learnt from sad experience. At present it is beyond her power to promise to cure cancer, whether by a cutting operation, by X-rays, by Finsen's light, or by any drug or nostrum injected into the blood, taken internally, or applied locally. Treatment is, unfortunately, not the same thing as cure, and the most effectual treatment for cancer-no matter how small it may be-is still removal by the knife."? 2

\section{NUBIAN ANTIQUITIES.}

$A \mathrm{~N}$ important philological discovery is announced A from Berlin. Profs. Karl Schmidt and $H$. Schäfer, who are well known for their work in connection with Coptic literature and Nubian antiquities respectively, have succeeded in making out something of the meaning of some religious documents of the eighth century A.D., written in Coptic characters, but in the Nubian language. The three Nubian dialects of to-day, Kenûs, Mahass, and Danakil, are not written. We have, of course, considerable knowledge of the grammar, \&c., of these modern dialects, but of the earlier history of the language but little is known. Hence the interest of Prof. Schmidt's discovery. If the two savants concerned succeed in making out more of the language, we may be able to decipher some of the few Nubian inscriptions written in Coptic characters which still exist.

In the description of the rock-cut grottoes of Gebel Adda, near Abu Simbel, in Murray's " Handbook for Egypt" (1896, p. 977), we find the following passage :- "On the walls are some Coptic inscriptions, and on the $\mathrm{S}$. wall of the adytum is a long text of I4 lines, in what Lepsius calls 'Christian Ethiopic,' of which another example exists on a rock (now partly broken) at the foot of the cliff on which Qasr Ibrim stands. The letters are those of the Coptic alphabet, but the language is unknown." This is the kind of

\footnotetext{
1 Brit. Med. Journ., 1906, i, p. 140.
2 Brit. Med. Journ, rgo6, ii., p. $168 \mathrm{r}$.

NO. I938, VOL. 75$]$
}

inscription referred to. Such records are very rare, and we fear that even when read they will prove to be of religious character, and will not throw the "light on the history of the earliest Nubian races" which the sanguine Berlin correspondent of the Globe (December I I) anticipates. The discovery referred to is published in the Abhandlungen of the Royal Prussian Academy of Sciences under the title "First Fragments of Christian Literature in the Old-Nubian Language."

The Old-Nubian inscriptions of Qasr Ibrîm and Gebel Adda are not referred to in Prof. Breasted's recently published report on the "Temples of Lower Nubia" (Chicago, 1906). We hope they have not suffered of late years. With regard to the grottoes of Gebel Adda, we note that on p. 18 of his report Prof. Breasted claims to have discovered a fact that has in reality been known for at least ten years, namely, that the ancient Egyptian Viceroy of Nubia, Paser, who cut a "memorial niche" for himself in this rock, lived in the reign of Eye (Ai) as well as in that of Harmhab (Horemheb). Prof. Breasted errs in his statement that Paser was "heretofore [? hitherto: heretofore can only refer to matter comprised in Prof. Breasted's previous pages] supposed to have been in office only under Harmhab." He will find the fact noted in the 1896 edition of Murray's " Egypt," probably by that indefatigable collector of Egyptian epigraphic material, Prof. Sayce.

Murray's book is especially useful for rock-tombs and inscriptions, and has far more detail of sites not usually visited by tourists than Baedeker has; but Prof. Breasted has religiously followed his German guide, and so has fallen into Baedeker's error of calling the temple of Serret el-Gharb, south of Gebel Adda, "the temple of Aksheh" (p. I7). This mistake was pointed out by Prof. Sayce in the "Recueil de Travaux" for 1895 , but still remains uncorrected. Aksheh, Aksha, or Akasheh, is many miles away, south of Wadi Halfa; there is a village called Eshka, however, not far off, which may be the origin of Baedeker's mistake.

\section{NOTES.}

THE following presidents of sections have accepted office for the meeting of the British Association to be held at Leicester next year:-A (Mathematics and Physics), Prof. A. E. H. Love, F.R.S.; B (Chemistry), Prof. A. Smithells, F.R.S.; C (Geology), Prof. J. W. Gregory, F.R.S.; D (Zoology), Dr. W. E. Hoyle; E (Geography), Mr. George G. Chisholm; F (Economics), Prof. W. J. Ashley; G (Engineering), Prof. Silvanus P. Thompson, F.R.S.; H (Anthropology), Mr. D. G. Hogarth; I (Physiology), Dr. A. D. Waller, F.R.S.; K (Botany), Prof. J. B. Farmer, F.R.S.; and L (Educational Science), Sir Philip Magnus, M.P.

The Royal Irish Academy held a very successful conversazione in the Academy House on December 4. Their Excellencies the Lord Lieutenant (visitor of the academy) and the Countess of Aberdeen were present, and a large and distinguished company accepted the invitation of the president and council. Some of the rare manuscripts in the possession of the academy were on exhibition, and attracted much attention; and interesting demonstrations were given in connection with recent scientific developments. There were shown by the fisheries branch of the Department of Agriculture and Technical Instruction for Ireland a number of important additions to the marine fauna of Ireland. Some new scientific instruments were 